\title{
Exploratory Study of E-Procurement Adoption in Indian and Chinese Companies: Case Study with Innovation Approach
}

\author{
Vijaykumar R. Salkute and Zonal Manager \\ National SCs Finance and Development Corporation, \\ (A Government of India Undertaking), 5th Floor, VV. Main Tower, Bangalore-560 032, India
}

Received 2012-07-19; Revised 2014-02-10; Accepted 2014-02-25

\begin{abstract}
Adoption of an E-procurement system offers a company many benefits in terms of tremendous cost savings and efficiency in procurement process. Therefore, E-procurement is constantly receiving lots of attention from companies in global markets. Although the benefits of e-procurement are plenty, the reality is that it is not being adapted to the much extent in developing countries. However, Indian and Chinese companies are planning to successfully adopt strategic approach for adopting e-procurement systems. Since the compatibility of e-procurement is somewhat barrier for implementation and integration of existing infrastructure, however in reality the cost savings are overpowering the risks. The present study explores how the tangible benefits and risks associated to e-procurement affect the e-procurement adoption and further explores the impact of e-procurement adoption in India and China. By using Indian and Chine firms, the results show that cost benefit is the main driver for companies to adopt e-procurement in India.
\end{abstract}

Keywords: E-Commerce, E-procurement, E-procurement Adoption, US, India, Business-to-Business, B2B

\section{INTRODUCTION}

In today's dynamic and competitive global business scenario, competitiveness force companies to undertake drastic and strategic initiatives to boost sales, increase flexibility and cut costs without considering about long term gains or losses. A well-conceived cost reduction strategy enables managers to capture maximum value in the form of direct savings. Organizations must embrace strategic cost reduction to facilitate a systematic cost reduction and building a solid organizational foundation that promotes a culture of cost reduction and efficiency. Business organizations are now under a tremendous pressure to improve their responsiveness and efficiency in terms of product development.

With the emerging application of E-commerce technologies, companies are forced to shift their operation from conventional way to a virtual ecommerce, e-procurement and e-auction philosophy.
These philosophies transform companies from a local business automation to a global enterprise and business automation (Lee et al., 2001). One such technological application which has higher profitability and higher cost savings is e-procurement. E-procurement has had an increasingly important role in Business-to-Business (B2B) commerce. Use of e-procurement not only lowers the cost of procurement but also provides better coordination between suppliers, quicker transaction time and increases process efficiency (Samaniego et al., 2006; $\mathrm{Wu}$ et al., 2007). However, even if the benefits of using e-procurement are high, its adoption has been at a very low stage. Despite the continued e-procurement discussion, there has been a paucity of research and development in term of its adoption. Some reasons for this occurrence is due to problems associated with people within the organizations to lack of ability to adopt the system, overheads associated with implementation and problem with persuading suppliers to implement e5th Floor, VV. Main Tower, Bangalore-560 032, India 
procurement (Talluri et al., 2006; Puschmann and Alt, 2005). If e-procurement is to obtain a strategic approach, due consideration needs to be given to how it can be strategically, operationally and technologically integrated. Organizations operating in the new economy need to align themselves internally with the demands that the dynamic environment imposes on strategic behavior (Phillips 2003). Supply managers now need to understand the impact of technology and gain competency in making a business case for e-procurement (Presutti, 2003).

E-procurement systems are generally used for buying and selling online Maintenance, Repair and Operation (MRO) goods as it can easily be transformed into ecatalogue. There is also possibility of using e-procurement for purchasing and selling direct goods, but there is still lack of acceptance in the industry towards this form of transition (Rajkumar, 2001). Most of the firms are inclined towards wait and see approach which makes them much careful and more observant (Davila et al., 2003; Bartezzaghi and Rochi, 2003; Carabello, 2001; Dhillon and Caldeira, 2000; Rasheed and Scott, 2001; Saunders et al., 2007; Stadler, 2002; Wilson, 2002; Yin, 2009 ).

Thus, the purpose of this study is to:

- To explore the impact of technology and gain competency in making a business case for eprocurement

- To explore how the e-procurement adoption is influenced by tangible cost benefits and risks associated to e-procurement

\subsection{Literature Review}

\subsubsection{Concept of E-Procurement}

With increasing use of e-commerce, procurement is going through a revolution. Procurement is migrating from traditional paper-based process to e-procurement with the increasing use of Internet and E-commerce technology (Chong et al., 2002). The main function of e-procurement system is that it allows individual employees to order goods directly from their personal computers through the web on a real-time basis. Requests and orders are channeled through various forms of hubs or database. It also allows individual employees to search for items, checks availability, place and track orders and initiate payment of delivery (Ovans, 2000). E-procurement includes purchasing, transportation, warehousing and inbound receiving (Kalakota and Robinson, 2001).

Strategically, the e-procurement changes the nature of procurement; from unskilled work to knowledge work, from meaningless repetitive tasks to innovation and caring, from individual work to teamwork, from functional-based work to project-based work, from single skilled to multi-skilled, from power of bosses to power of customers, from coordination from above to coordination among peers. Generally e-procurement system has two essential components:

- Internal processing which is corporate intranet and

- External communication processing which is internetbased platforms (Crooms and Johnston, 2003)

\subsection{Definition of e-Procurement}

E-procurement is a collaborative procurement of goods, works and services using electronic methods in every stage for bringing efficiency and transparency. Eprocurement allows organizations to conduct the purchasing process over the Internet without the use of paper. There are number of definitions for e-procurement.

"E-procurement or electronic procurement is an automated, Internet-based way for a company to purchase the goods and services it needs to conduct business."

However, in the present study, the definition of eprocurement is in line with the study of Wu et al. (2007), whom define e-procurement as 'use of information technology to facilitate Business-to-Business (B2B) purchase transaction for a materials and services'.

\subsection{Benefits of e-Procurement}

According to (Kalakota and Robinson, 2001), the benefits of e-procurement fall into two major categories viz. efficiency and effectiveness. Efficiency includes lower procurement costs, faster cycle times, reduced maverick or unauthorized buying, more highly organized information and tighter integration of the procurement function with key back-office systems. Effectiveness includes increased control over the supply chain, proactive management of key procurement data and higher-quality purchasing decisions within organizations. In order to adopt the e-procurement, the cost benefits of e-procurement could be viewed as a major driving force. The present study reviews benefits of e-procurement identified in previous studies and proposes the main benefits commonly referred in literatures.

\subsection{Tangible Cost Savings}

E-procurement can improve tangible cost savings. But E-procurement is no longer just a transaction center for placing orders but can also be a source of competitive advantage by acting as an information hub supporting business planning and decision making. However, Cost reduction and negotiation are the reason for transaction costs fall so precipitously with e-procurement (Ovans, 2000). Reductions in labour costs in the purchasing 
process, increase in purchase volume, leads to better price from supplier and better negotiation, i.e., suppliers are ready to reduce the price as they get the assurance of transaction from the buying company. Davila et al. (2003) suggest that cost per transaction using eprocurement can be reduced by $65 \%$ compared to traditional procurement transaction.

\subsection{Better Information Flow and Collaboration Between Buyers and Suppliers}

E-procurement can streamline internal processes while enhancing supplier relationships. Interoperability of a firm allows different applications and systems to perform functions while communicating to exchange data with one another or operating seamlessly. This can occur within one agency or across multiple agencies. Therefore, implementing e-procurement solution does not always require additional technology, dedicated personnel or staffing resources. Existing technology infrastructure including equipment and computers with internet connectivity, which are common equipments used in most companies nowadays, is sufficient (Quayle, 2005).

\subsection{Control over Maverick Spending}

Maverick spending is purchasing goods or/service in non-compliance with your policies. Nobody wants to have those feeling but it happens sometime in procurement process. E-procurement system uses internet technology that allows the firm to minimize the maverick spending.

\subsection{Risks Associated With E-Procurement}

Dai and Kauffman (2001) argue that internet-based eprocurement systems and B2B electronic market solutions need to be compatible to the greatest possible extent with the existing technologies, to have a reasonable chance to be widely adopted in the marketplace. Four categories of risk are identified within the literature related with eprocurement viz. Internal business risk, External business risk, technological risk and process risk. Some of the process risks are briefed as under.

\subsection{Operations-Process Risks}

- Human resources risk if the personnel do no possess the requisite knowledge, skills or experience to manage the new process

- Sourcing risk because there will be fewer alternative sources, thus increasing the risk of shortage and

- Business Interruption risk due to the dependence on a smaller number of suppliers who may be exposed to significant risks of their own

\subsection{Empowerment-Process Risks}

- Leadership risk if purchasing managers do not have the vision and management to properly oversee the new business process

- Authority/limit risk if management has not clearly defined the spending levels of end users previously managed by the purchasing department

- Change readiness risk if the organization does not assimilate large-scale change easily

\subsection{Information Technology-Process Risks}

- Infrastructure risk related to application system deployment, logical security, database management and business/data centre recovery

- Relevance risk because the integration required may not deliver the "right data/information to the right person/process/system at the right time to allow the right action to be taken"

- Access risk because of the dramatic increase in end users not normally accessing purchasing information

- Integrity risk in the areas of user interface, processing, error processing and interfaces

- Availability risk because of the dependence on the Internet for supplier linkage and processing risk at the supplier site

\subsection{Integrity-Process Risks}

- Management fraud risk associated with a smaller set of supplier who has "exclusive" relationship

- Employee fraud risk as purchasing oversight is minimized regarding the transactions and

- Unauthorized use risk if the internal and external controls are not sufficient

\subsection{Financial-Process Risks}

- Price risk if there is not sufficient oversight to the prices contained in the catalogs

- Liquidity risk if there are insufficient controls related to cash flow risk and concentration risk

- Settlement risk if there are quality or delivery issues with a reduced number of suppliers and

- Market risk if the suppliers are also supplying similar products to the competition

\subsection{Decision Making-Risks}

- Performance measurement risk if the new metrics are not informative, understandable, believable, actionable or cannot initiate change 
- Accounting information risk if the procurement system is not adequately integrated with financial processes and systems and

- Organization structure risk if the purchasing department is not utilized to provide more valueadded services

\subsection{E-procurement Adoption}

The present study emphasizes the e-procurement adoption in three dimensions; strategy, practice and adoption model. The details of each dimension are described in the following.

\subsection{E-procurement Strategies}

Davila et al. (2003) suggests three different approaches in adopting e-procurement; wait-and-see, passive and aggressive approach.

\subsection{Wait-and-See Group}

Companies are aware of the developments but do not perceive the current state of development merits shifting their established procurement process to the e-world. The strategy reflects active experimentation but no sizeable investment until the best e-procurement model is defined.

\subsection{Passive Group}

In this, the adequacy (and risk) will depend on how quickly organizational learning can be absorbed without creating the absorptive capacities that the wait-and-see companies seem to be developing. The logic behind this approach is that a firm wants to declare that they are investing significantly to gain a competitive lead or moving fast into e-procurement solutions. This strategy, however, is defined as riskier in the absence of any welldefined solution and companies may end up betting on the wrong technology.

\subsection{Aggressive Approach}

In this approach, companies believe that their competitors are implementing e-procurement system and that forcing them to pursue an aggressive approach.

\subsection{E-procurement Practices}

In the e-procurement circle, there have been two practices:

- Direct material (or purchases) and

- Indirect material (or purchases)

Indirect materials are typically referred to as MRO goods where as direct materials are those that are closely linked to production or service delivery. Mostly companies are purchasing either direct or indirect materials on the internet. The research done by the ISM (2002) indicates a consistent growth in the adoption of web-based methods for indirect purchases. However, it is more difficult to implement e-procurement for direct material as it requires lot 'back end integration' and complex procedures (Rajkumar, 2001).

\subsection{E-procurement Models}

There have been three types of E-procurement models in literature:

- Buy-side procurement

- Sell-side procurement

- E-marketplace and trading hubs

The first application is the buy-side procurement which refers to an organization using electronic systems to purchase goods, such as office stationary, from contracted suppliers. In short, this model is generally driven by the specific requirements of the buying organizations than other models.

The second application is sell-side procurement which is used to describe how one supplier sells to a number of buying organizations using electronic systems viz. e-procurement systems, e-commerce technology. Sell-side procurement model is often used extensively in Business-to-Consumers (B2C).

The last application is e-marketplace and trading hubs which is a combination of industry consortium and the trading exchanges. The marketplace model brings together many different buying and selling organizations in one trading community. The most popular e-marketplace function is auction used for variety of product category. This type of model often helps to increase collaboration between companies in a single industry sector or providing the opportunity of e-procurement to companies who would normally be too small to benefit.

\subsection{Analytical Framework}

The analytical framework has been designed to visualize the association among cost benefits, risks and e-procurement adoption in Indian Textile Companies and Chinese toys companies. It is expected that the way eprocurement is adopted is more or less influenced by a firm's perceived tangible benefits and risks. The eprocurement adoption consists of three dimensions; strategy, practice and model. These three dimensions are assessed to see what makes a firm to employ a particular strategy, practice and model. Figure 1 shows the analytical framework for the present study. 


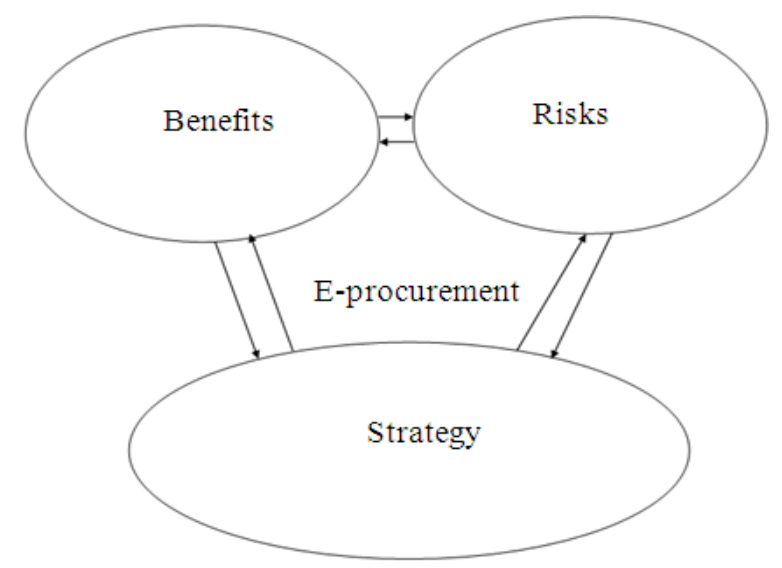

Fig. 1. E-procurement adoption

\subsection{Research Framework}

The present study is an exploratory research aiming to see if the differences or similarities exist among firms in different setting.

Indian textile companies and Chinese toys companies were selected. The sample criteria was based on companies that have implemented e-procurement solutions or/and those who help to provide e-procurement solution to other companies. The reason for taking these two perspectives is that, when a company has adopted e-procurement, it is easy to get in-depth information and when a company is providing e-procurement solutions, it is easier to get wider information about its customers (companies) issues and challenges related with adoption of e-procurement. These two perspectives were further used to compare the views between Indian and Chinese companies.

\subsection{Methodology and Data Collection}

A survey technique was used in the study. Total of twenty companies were selected for the study from India and China (Companies of Textile [P] and Toys [Q] respectively). Only well-established companies were selected for the study and the criteria for that were either they are using or providing e-procurement services for at least five years or more. This criterion secured a higher possibility for better information regarding the research area. The companies approached for the study were first contacted via e-mail. Regarding e-procurement solution provider from India Company $[\mathrm{P}]$ which qualifies under these criteria. All textile [P] and toys [Q] companies of Indian and Chinese countries respectively were founded around the year 2005. Also, all are leading eprocurement service provider in their respective country. While selecting users of e-procurement, it was purposeful that the user company should be related with the service provider company. So, a Chinese [Q] company was selected for India as company $[\mathrm{P}]$ provides the e-procurement solution to company [Q] and company $[\mathrm{Q}]$ is a market holder of company [P]. Another reason for selecting these companies was due to their involvement in the B2B sector. In addition, it was purposefully tried to take not only companies from different countries but also different industry as this widens the scope of the study for a better understanding of the e-procurement phenomena.

Data collection was done using e-mail survey and documentation. Follow-up was conducted via second reminder with the help of e-mails. Websites of each company was used as an important source for documentation and information. It was difficult to find the right person within each company and especially within the uses company's of e-procurement. Thus, no specific positioned person was selected from each company but rather the most appropriate person with the answers was sought within the companies. All persons in both the companies were at managerial level and were the responsible person for the operations of eprocurement systems. Before the survey, a brief description of the research was provided, which include objective of the study and the guideline regarding the contribution expected from the interviewees. Finally, interviewees were confirmed about the confidentially of sensitive data. During the survey, notes were taken and the data was recorded for higher reliability. For data analysis within and cross-case analysis was performed, which will be presented in the next section.

\subsection{Findings and Analysis}

\subsubsection{Findings From Indian and Chinese Cases (Companies $[\mathrm{P}]$ and $[\mathrm{Q}]$ )}

\subsubsection{Tangible Benefits}

Cost saving is recognized in accordance with the findings presented by different authors. In company [Q], high purchase volume helps in getting better price and higher tangible cost savings from supplier. Company $[\mathrm{P}]$ also confirmed the literatures and identified tangible cost saving as the main factor for company to adopt eprocurement. Moreover, e-procurement assures the suppliers and buyers making negotiation more natural. Company [Q] partially allied with the concept relating to process efficiency. It helps in getting market overview, transparency throughout the company and reduction in the overall purchasing. They also associated process efficiency with reduction in numbers of suppliers, i.e., in invoicing and other information from suppliers. Similar 
view was shared by company $[\mathrm{P}]$, establishing that process efficiency enables better business control, professionalism in work and clears up other processes within the company. Further, both firms suggested time convenience as a vital benefit, users can utilize their time at work rather than purchasing.

Regarding Better Information flow and Collaboration between buyers and supplier, company [Q] agreed with the concept completely whereas, company $[\mathrm{P}]$ partially agreed. They explained that e-procurement solutions enable end-users to search for products to create requisitions and to place orders with supplier. But, the employees lbuyers may not always know the supplier. Thus, no direct relationship may come to exist and information flow might be restricted. Both companies [P] and [Q] fully approved reduction in maverick spending due to e-procurement adoption. They acknowledged contract compliance, i.e., purchase only from suppliers with whom they already have some relationship, which leads to controlled/reduced maverick spending. Finally, the most important benefit of e-procurement for company [Q] was tangible cost savings as non-cost savings are rather intangible. Whereas, company $[\mathrm{P}]$ did acknowledge non-cost benefits to be not existing and better price to be the main motivator. It also rates contract compliance and process savings as important benefits.

\subsection{Tangible Risks}

Company [Q] partially related information technology-process risks with the implementation of eprocurement, as suppliers have shown interest in integrating e-procurement but found it to be very expensive to integrate with their existing system. The company had to provide training and educate its employees on proper usage of e-procurement. However, there was no problem with the integration and uncertainty of its current IT solution. For company [P], information technology-process risks did not exist; this was due to technological advancements, training the employees and other services. The company revealed something new and interesting to be added to the literature; identifying other integrity-process risks like lack of managerial commitment and need for change in behavior and management. Company [P] did not support the concept of financial-process risks, the only visible risk was that the suppliers did not want to join the system (mostly a risk for smaller companies rather than large companies) while other risks related to the suppliers were taken care of before any transaction. Company [Q] believed that there can be risk while dealing with new suppliers as they may not be interested in a marketplace that is expensive. It is seen as extra burden for suppliers for delivery which might discourage suppliers. On the other hand, buyers may get confused who to choose from the large supply base. Technological risks were not of great concerned to both companies [P] and [Q] as eprocurement technology standard has been commonly and widely accepted. Hence, this risk is obsolete. Nonetheless, both companies were more or less threatened by process risks. Company [Q] gave high priority to security which should not be neglected. It has a separate security and audit department. As the information is vital, it should not be visible to competitors. Despite the security, measures good communication between all players in the marketplace is essential. In contrast, company $[\mathrm{P}]$ rated risks linked to security and control issues very low.

\subsection{E-procurement Adoption}

Company $[\mathrm{P}]$ diverged from the concept. The company believed wait and see approach was quite common oneyear back in the industry. But now, a different approach is adopted by companies regarding implementing eprocurement. It is somewhere between passive and aggressive approaches like a moderate approach. Company $[\mathrm{P}]$ considered several business case studies and analysis before making decision to implement eprocurement system. Nevertheless, the company was positively implementing e-procurement system. The company felt that the transformation was due to change in company's overview regarding e-procurement, as it was not just a new software solution. Tangible risks have significantly reduced and the communication of eprocurement adoption has become easier than before.

Company [Q] followed wait and see approach when it first implemented e-procurement system. The company ran a test pilot with just 20 users with few suppliers in 2010. It did not take the company long to understand the benefits associated with e-procurement and the initial risks conquered. The users got compatible with the system and within a year, the company changed it strategy to aggressive approach. The company widely implemented the solution by June 2008 and added 100 users; across all branches in China. By November 2009, all the employees of company [Q] in China were able to use e-procurement solution.

Although the current use of e-procurement is for indirect material, there is a rise in the purchase of direct material. It can be seen that in the near future, more transaction of direct material will be done. The acceptance of eprocurement solutions has got suppliers more interested to get involved. Company [Q] supported the argument as its current e-procurement technology was used only for indirect material due to the needs of their business process. 
Company $[\mathrm{P}]$ provides buy side e-procurement model as it is e-procurement vendor. The company explained that it is easy to motivate suppliers if you have big companies as buyers (e.g., Reliance, Tatas). Suppliers were assured that the adoption of e-procurement will yield them better relations with their customers leading them to earn more money. This model is easier to sell as compared to sell side or trading hubs. The model adopted by company [Q] is a buy side model and the reason for choosing this specific model is influenced by the need for more specific solution for company [Q].

Sell side or trading models is not considered because both did not meet the company's procurement needs.

\section{DISCUSSION}

The findings of the present study reveal several interesting issues. It could be argued that tangible cost benefits are the drivers for companies to implement eprocurement solution. Although the risks are presented throughout the process, the tangible cost benefits clearly over power them. In particular, tangible cost saving is identified by all Indian and Chinese companies as the main motivator for them to implement e-procurement. It is easy to speak about cost benefits compared to other benefits as its effect is easily noticeable on the company's balance sheet.

It is stressed that e-procurement leads to professionalism in work, better business control and cleans up the processes within the company. The study confirms prior researches indicating that there is an association between the benefit of better information flow between buyers and suppliers and eprocurement adoption. Some of the main points worth mentioning are increase in number of transactions, transparency in process, standardization of best practice and increases in responsiveness to customers. This benefit eventually leads to the firm's saving from investments and increasing of revenue.

A consensus between the companies is documented regarding the reduced maverick spending. They all confirm using a recognized supplier for purchasing products leading to better control and regulate spending. Moreover, a transaction is easier and less expensive for a company.

Tangible Cost benefit is only recognized as important and essential benefit of e-procurement. Furthermore, the risks associated with e-procurement are perceived. Some firms also suggest additional risks which can be added to the knowledge in this research field. Regarding operation process risks, companies identify the need to provide proper training at all levels for better understanding and collaboration across the organization. Investigation of the China based e-procurement provider enlightens the lack of managerial commitment constraining the adoption of e-procurement. Hence, the need to change the overall behavior and management is acknowledged. The findings suggest that process risks associates with eprocurement should be given attention as well. There are risks of dealing with new customers with no previous records, lack of integration between the system used by the suppliers and the companies and connectivity.

Adoption of e-procurement is slow and results are delayed mostly due to lack of technological standards. A similar view is shared by both Chinese and Indian companies. But the technology seems to be standard in China while it is not in India. Regarding to security and control, they seem to differ to each other. Based on the finding, both China and India, it can be understood that these risks are more fundamental during the initial phases of implementation of e-procurement, but once the roles get defined it becomes part of a system or process.

Regarding the adoption strategy, it could be stated that companies change their strategic approach to suit their needs. Although they recognize the three different strategic approach regarding e-procurement. But companies do not necessarily have to choose one strategic approach and stick with it rather one could starts with one approach and changes to another later on to convene its current requirements. Also, some companies in Chinese were aiming towards a moderate approach which is a combination of passive and aggressive approach. These companies recognized benefits of e-procurement and were in the process of implementing the service. For the eprocurement practices, both direct and indirect materials are purchased from the e-procurement solution. Prior researches suggest that indirect materials are more likely purchased by e-procurement solutions (Rajkumar, 2005). However, there is a rapid change in the market scenario in both countries towards direct material purchase. The findings of this study also confirm the finding in previous researches. In other words, companies recognize all three models in the adoption of e-procurement but the buy side procurement model is mostly implemented. This could be explained that a specific requirement of the buying organizations is met by this model as compared to other models. Other factors that help in influencing this decision are large customer base for suppliers and big players assure suppliers of better revenue and relations. 


\section{CONCLUSION}

We started this research with the purpose to understand risks, tangible benefits and adoption process of eprocurement. It can clearly been seen that benefits related with e-procurement are overpowering the risks and the risks are diminished with the passage time and number of companies will be adopting e-procurement in near future. Cost reduction was acknowledged as the most important benefit with e-procurement. Intangible benefits were hard to observe but still they had significant influence on companies using or providing e-procurement services. Commitment of top management could drastically hinder implementation of e-procurement. Companies did not regard technological and security as a risk with e-procurement. This can be due to the development of more standardized e-procurement services and acceptance within the industries.

Both Chinese and Indian companies identified all three strategic approaches within their industries. But they also recognized that companies had moved from one approach to another and currently had more positive outlook towards implementing e-procurement services. Although, in past the trend had been towards purchasing mainly indirect material using e-procurement, companies were also understanding benefits with purchasing direct material with this medium. Finally, buyer side model were most dominate in both countries. This might be influenced by the scenarios under study as both companies $[\mathrm{P}]$ and [Q] were powerful buyers. Overall, we would like to conclude that we have provided some interesting insights towards the research domain of e-procurement adoption.

\subsection{Limitations and Suggestions for Future Research}

There are some limitations in this study. First, since the study is exploratory research, the sample used is not intended to be representative for Chinese and Indian firms. The selectivity of Textile and Toys firm is relatively limited to research generalization. However, as a case study base, the sample is sufficient to contribute the knowledge to the research community. More samples are needed in future research to generalize the findings. Second, the differences and similarities found in the study are based on qualitative data. The future research might employ quantitative data to validate the outcome of this study. Lastly, the study only emphasizes in China and India. It would be interesting to include other countries into the future research. A comparative research is needed to consolidate the knowledge to the research community. Consequently, the results presented here should be interpreted in light of these limitations.

\section{REFERENCES}

Bartezzaghi, E. and S. Rochi, 2003. Internet supporting the procurement process: Lessons from four case studies. Int. Manufact. Syst., 14: 632-641. DOI:10.1108/09576060310503447

Carabello, L., 2001. E-procurement can reduce expenses. healthcare Financ. Manage., 55: 82-83. PMID: 11765639

Chong, P.P., E.T. Chen and J.C.H. Chen, 2002. EProcurement in taiwan: Issues and viewpoints. Rev. Pacific Basin Finan. Markets Pol., 5: 521-531. DOI: 10.1142/S0219091502000912

Crooms, S. and R. Johnston, 2003. E-service: Enhancing internal customer service through e-procurement. Int. J. Service Indust. Manage., 14: 539-555. DOI: $10.1108 / 09564230310500219$

Dai, Q. and R.J. Kauffman, 2001. Business models for Internet-based e-procurement systems and B2B electronic markets: An exploratory assessment. Proceedings of the 34th Hawaii International Conference on Systems Science, Jun. 3-6, IEEE Xplore Press, Washington, pp: 10-20. DOI: 10.1109/HICSS.2001.927035

Davila, T., M. Gupta and R.J. Palmer, 2003. Moving procurement systems to the internet: The adoption and use of e-procurement technology models. Eur. Manage. J., 21: 11-23.

Dhillon, G. and M. Caldeira, 2000. Interpreting the adoption and use of EDI in the Portuguese clothing and textile industry. Manag. Comp. Security, 8: 184188. DOI: $10.1108 / 09685220010344934$

ISM, 2002. ISM/Forrester research reports on Ebusiness. Institute for Supply Management.

Kalakota, R. and M. Robinson, 2001. E-business 2.0: Roadmap for Success. 1st Edn., Addison-Wesley Professional, Boston, ISBN-10: 0201721651, pp: 520.

Lee, J., J. Ni, and N. Koc, 2001. Draft report NSF workshop on Teether free technology for emanufacturing, e-maintenance and e-service, organized. NFS industry/University Co-operation Research Center, Wisconsin, USA.

Ovans, A., 2000. E-procurement at schlumberger. Harvard Bus. Rev.

Phillips, P.A., 2003. E-Business Strategy: Text and Cases. 1st Edn., McGraw-Hill, London, ISBN-10: 0077098374, pp: 390.

Presutti, W.D., 2003. Supply management and eprocurement creating value added in the supply chain. Ind. Market. Manage., 32: 219-226. DOI: 10.1016/S0019-8501(02)00265-1 
Puschmann, T. and R. Alt, 2005. Successful use of eprocurement in supply chains. Supply Chain Manage. Int. J., 10: 122-133. DOI: $10.1108 / 13598540510589197$

Quayle, T., 2005. The (real) management implications of e-procurement. J. General Manage.

Rajkumar, T.M., 2001. E-procurement: Business and technical issues. Inf. Sys. Manage.

Rasheed, H.S. and W.G. Scott, 2001. Determinants of governance structure for the electronic value chain: Resource dependency and transaction costs perspectives. J. Bus. Strateg., 18: 159-176.

Samaniego, M.J.G., A.M.G. Arranz and R.S.J. Cabezudo, 2006. Determinants of internet use in the purchasing process. J. Business Ind. Marketing, 21: 164-174. DOI: $10.1108 / 08858620610662813$

Saunders, M., P. Lewis and A. Thornhill, 2007. Research Methods for Business Students. 5th Edn., Pearson Education, Harlow, ISBN-10: 0273716867, pp: 656.
Stadler, C.A., 2002. Success Guide for E-procurement, Info-Tech Research Group (ITRG). 1st Edn., Ontario, London, pp: 22.

Talluri, S., W. Chung and R. Narasimhan, 2006. An optimization model for phased supplier integration into e-procurement system. IIE Tran., 38: 389-399. DOI: $10.1080 / 07408170500306554$

Wilson, C.L., 2002. 'E-procurement and energy. Power Economics, 6: 12.

Wu, F., G.A. Zsidisin and A.D. Ross, 2007. Antecedents and outcomes of e-procurement adoption: An integrative model. IEEE Tran. Eng. Manage., 54: 576-586. DOI: 10.1109/TEM.2007.900786

Yin, R.K., 2009. Case Study Research: Design and Methods. 4th Edn., Sage, London, ISBN-10: 1412960991, pp: 291. 